ISTIGHNA, Vol. 2, No 2, Juli 2019 P-ISSN 1979-2824 E-ISSN 2655-8459

Homepage: http://e-journal.stit-islamic-village.ac.id/index.php/istighna

Fatqu Rois dan Himatul Munawaroh

Peran Sentralistik Kiai dalam Mengembangkan Pola Manajerial dan Out Put

Madrasah Diniyah di Era Milenial

\title{
PERAN SENTRALISTIK KIAI DALAM MENGEMBANGKAN POLA MANAJERIAL DAN OUT PUT MADRASAH DINIYAH DI ERA MILENIAL
}

\author{
${ }^{1}$ Fatqu Rois \\ Institut Agama Islam Ngawi \\ email: fatqurois06@gmail.com \\ ${ }^{2}$ Himatul Munawaroh \\ MTs PSA An-Noor Ngawi \\ email: iemmanafila17@gmail.com
}

\begin{abstract}
Kiai is the applellaton for man teaching Islamic knowledge in Indonesia he have urgent role for the society. Kiai have many methods for spread to doctrine of Islam in society. One of many methode from kiai with based diniyah school. Diniyah school now had heavy problem can bringing into annihilate this place is decrease amount of santri(applellation of students in diniyah school). Kiai as the leader from diniyah school have strong influence so succeed or broken it depend on from mindset and act kiai. Kiai must know a problem in diniyah school and making many methods to giving many skill out put. Kiai must expand insight and conections for diniyah school still excist and can giving out put multy talent in society.
\end{abstract}

\section{Keyword: Leader; Kiai; Diniyah School}

\begin{abstract}
Abstrak: Kiai sebutan bagi seseorang yang mengajarkan tentang ilmu agama Islam di Indonesia yang mempunyai peranan penting bagi masyarakat. Seorang kiai mempunyai berbagai metode dalam mensyiarkan agama islam di masyarakat. Metode yang digunakan salah satunya adalah berbasis Madrasah diniyah. Saat ini madrasah diniyah mengalami masalah yang cukup kronis yang dapat membahayakan eksistensinya yaitu menurunnya jumlah santri yang belajar disana. Kiai sebagai penentu arah madrasah diniyah tentu mempunyai pengaruh yang sangat kuat, sehingga maju mundurnya suatu madrasah diniyah tergantung dari pola pikir dan tindak tanduk dari kiainya. Kiai harus mengetahui problematika yang ada dalam madrasah diniyah serta harus mampu membuat metode-metode praktis guna memperkuat lulusannnya. Kiai juga hendaknya memperluas wawasan dan koneksi supaya madrasah diniyah tetap eksis dan bisa memberikan lulusan yang bisa mandiri di masyarakat.
\end{abstract}

Kata kunci: Kepemimpinan; Kiai; Madrasah Diniyah

\section{A. PENDAHULUAN}

Kiai adalah term untuk mengungkapkan sesuatu atau jabatan terhadap sesuatu yang diannggap mempunyai kekuatan lebih. Kiai juga dapat diartikan orang orang yang lebih mengerti bahwa Allah SWT dzat yang berkuasa atas 
ISTIGHNA, Vol. 2, No 2, Juli 2019 P-ISSN 1979-2824 E-ISSN 2655-8459

Homepage: http://e-journal.stit-islamic-village.ac.id/index.php/istighna

Fatqu Rois dan Himatul Munawaroh Peran Sentralistik Kiai dalam Mengembangkan Pola Manajerial dan Out Put Madrasah Diniyah di Era Milenial

segala sesuatu. ${ }^{1}$ Gelar ini diberikan masyarakat jawa kepada seseorang yang ahli dalam Agama Islam yang menjarkan kitab-kitab klasik kepada santrinya. ${ }^{2}$ Ciri dari kiai secara fisik biasa sering memakai sarung, surban dan kopiah. ${ }^{3}$

Seorang kiai sangatlah dihormati dilingkungan sekitarnya apalagi dalam lingkup madrasah diniyah. Mereka menganggap bahwa kiai mempunyai peranan sentral dalam pendidikan di madrasah diniyah. Pengaruh kiai terletak pada keutamaan ilmunya yaitu ilmu agama (Islam). Santri menganggap tiangnya madrasah diniyah atau pesantren adalah seorang kiai, jadi mereka menghormati sosok kiai mereka. Kiai mempunyai kedudukan layaknya orang tua ketika mendidik dan bertanggung jawab atas kehidupan mereka ketika mengenyam pendidikan di pondok pesantren ataupun di madrasah diniyah.

Masalah utama yang dialami madrasah saat ini adalah kurangnya animo masyarakat menyekolahkan anaknya ke madrasah diniyah, belum lagi masalah lainnya. Bukan hal yang tidak mungkin lambat laun madrasah diniyah akan kehilangan eksistensinya. Kiai yang merupakan manajer dari madrasah diniyah perlu untuk memperbaiki berbagai masalah yang makin kompleks. Kiai dengan wasilah madrasah diniyahnya sudah banyak mencetak generasi yang berkarakter penuh dengan wawasan keIslaman, untuk itulah lembaga ini hendaknya lebih banyak mendapatkan perhatian.

\section{B. METODE KAJIAN}

Metode Kajian yang digunakan adalah kualitatif, metode penyajian datanya adalah deskriptif analisis, serta dirancang dengan pendekatan kepustakaan yang menelusuri beberapa literatur yang berkaitan dengan pembahasan tentang peran sentralistik kiai dalam mengembangkan pola manajerial dan out put madrasah diniyah di era milenial.

\section{HASIL DAN PEMBAHASAN}

\section{Madrasah Diniyah dan Tantangan Era Milenial}

Madrasah diniyah adalah isntitusi pendidikan unik dan eksklusif. Madrasah diniyah mempunyai fungsi untuk mengentaskan kebodohan. Guru madrasah diniyah kebanyakan lebih mengutamakan aspek perilaku dari pada aspek pemikiran. Madrasah mempunyai tujuan untuk mengganti ideologi negatif menjadi ideologi keislaman yang positif. Madrasah diniyah didirikan kiai untuk menjadi start up mindset dari apa yang diinginkannya. Hanya lewat pendidikanlah upaya merubah mindset bisa dilakukan.

Madrasah diniyah merupakan kata serapan bahasa Arab bisa dipisah menjadi dua kata yakni madrasah dan diniyah. Madrasah berarti tempat untuk belajar dan diniyah adalah agama, jadi tempat belajar keagamaan(Islam) adalah definisi madrasah diniyah secara kebahasaan. Dua stuktur kata yang dijadikan satu tersebut, madrasah diniyah berarti

\footnotetext{
${ }^{1}$ Hamdan Rasyid, Bimbingan Ulama: kepada Umara' dan Ummat (Jakarta: Pustaka Beta, 2007). hlm. 18

2 Zamakhsyari Dhofier, Tradisi Pesantren: Study tentang Pandangan Hidup Kiai (Jakarta: LP3S, 1982) hlm. 55

${ }^{3}$ Ibid, hlm 56
} 
ISTIGHNA, Vol. 2, No 2, Juli 2019 P-ISSN 1979-2824 E-ISSN 2655-8459

Homepage: http://e-journal.stit-islamic-village.ac.id/index.php/istighna

Fatqu Rois dan Himatul Munawaroh Peran Sentralistik Kiai dalam Mengembangkan Pola Manajerial dan Out Put Madrasah Diniyah di Era Milenial

tempat belajar masalah keagamaan, dalam hal ini agama Islam. ${ }^{4}$ Adapun dari segi istilah madrasah diniyah adalah institusi Pendidikan yang khusus mengajarkan pelajaran agama Islam secara detail dan menyeluruh.

Tujuan belajar adalah bukan hanya bisa memahami konsep pengetahuan semata. Namun, untuk mengembangkan dirinya menjadi makhluk yang berahlaqul karimah serta melahirkan kesejahteraan spiritual, mental dan fisik bagi keluarga, bangsa serta seluruh umat manusia. ${ }^{5}$ Apalagi dalam madrasah diniyah penekanan aspek kepribadian religious selalu ditonjolkan hal ini sangat penting bagi kehidupan karena jika sudah lepas dari madrasah alumni akan tetap berjiwa Islami walau apapun kondisinya.

Madrasah diniyah adalah salah satu lembaga pendidikan keagamaan pada jalur luar sekolah yang diharapkan mampu secara menerus memberikan pendidikan agama Islam kepada anak didik yang tidak terpenuhi pada jalur sekolah yang diberikan melalui sistem klasikal serta menerapkan tiga jenjang pendidikan yaitu madrasah diniyah awaliyah, wustho dan ulya ${ }^{6}$.

Kurikulum madrasah diniyah lebih condong pada suatu paham tertentu. Pelajaran yang diajarkan oleh guru tidak berubah dari masa ke masa kecuali penambahan mufrodath (kosa kata) pada pelajaran bahasa Arab. Adapun jenis pelajaran yang diajarkan dalam madrasah diniyah adalah Fiqih, Tafsir, Tauhid ${ }^{7}$, Al-Qur'an Hadits, Aqidah Akhlak, Sejarah Kebudayaan Islam, Bahasa Arab dan Praktek Ibadah. ${ }^{8}$

Madrasah diniyah dahulu mendapatkan tempat yang strategis dalam opsi pendidikan masyarakat terutama dalam hal pendidikan agama Islam. Kiranya dahulu kala madrasah diniyah adalah tempat belajar yang murah dan dampaknya langsung dapat dirasakan oleh masyarakat luas. Para santri yang sudah tamat belajar dari madrasah diniyah dapat diandalkan secara positif baik dari segi dakwah Islamiyah dan responsif terhadap kebutuhan masyarakat.

Madrasah diniyah di era sekarang ini bisa dikatakan mengalami kemunduran walaupun pada hakikatnya masyarakat tahu bahwa lewat kegiatan dalam madrasah diniyah perilaku negatif dapat diturunkan lewat penanaman akhlaqul karimah yang selalu diajarkan di madrasah diniyah tersebut. Kenyataannya banyak madrasah diniyah yang mengalami kemunduran hal ini terlihat dari sepinya peminat sampai tingkat atas. Kebanyakan santri yang bersedia belajar di madrasah diniyah hanya di level sekolah dasar formal. Santri yang berumur setelah 13 tahun lebih memilih

\footnotetext{
${ }^{4}$ Haedar Amin dan Elsaha Isham, Peningkatan Mutu Terpadu Pesantren dan Madrasah Diniyah (Jakarta: Diva Pustaka, 2004), hlm. 14 27

${ }^{5}$ Muhaimin, Paradigma Pendidikan Islam, (Bandung: PT. Remaja Rosdakarya, 2004), hlm.

${ }^{6}$ Direktorat Pendidikan Keagamaan \& Pondok Pesantren Dirjen Kelembagaan Agama Islam, Pedoman Penyelenggaraan dan Pembinaan Madrasah Diniyah, (Jakarta: Departemen Agama RI, 2003), hlm. 7

${ }^{7}$ Haedar Amin dan Elsaha Isham, Peningkatan Mutu Terpadu..., hlm. 39

${ }^{8}$ M. Ishom Saha, Dinamika Madrasah Diniyah di Indonesia :Menelusuri Akar Sejarah Pendidikan Nonformal (Jakarta: Pustaka Mutiara, 2005), hal. 42
} 
ISTIGHNA, Vol. 2, No 2, Juli 2019 P-ISSN 1979-2824 E-ISSN 2655-8459

Homepage: http://e-journal.stit-islamic-village.ac.id/index.php/istighna

Fatqu Rois dan Himatul Munawaroh

Peran Sentralistik Kiai dalam Mengembangkan Pola Manajerial dan Out Put

Madrasah Diniyah di Era Milenial

keluar dari madrsah diniyah dengan dalih sekolah menengah atas sudah menguras waktu belajar mereka. Hal ini jika terus dibiarkan maka madrasah diniyah hanya akan ada dalam buku sejarah padahal manfaat dari penhajaran dalam madrasah diniyah begitu besar. Pihak madrasah diniyah harusnya merasa prihatin dengan fenomena laten ini.

\section{Metode Kiai dalam Mengembangkan Madrasah Diniyah}

Menghadapi tantangan zaman dalam mempertahankan eksistensi madrasah diniyah maka kiai melakukan berbagai macam usaha. Kiai yang menjadi ujung tombak madrasah diniyah sangat berhak merubah pola dan arah masa depan madrasah. Madrasah diniyah saat ini kondisinya akan semakin terpuruk jika kiai tidak melakukan metode yang efektif untuk mempertahankan eksistensi dan memajukannya.

a. Metode pengembangan internal

Metode pengembangan internal meliputi pengembangan kemampuan guru dan out put madrasah. Pengembangan guru adalah hal mutlak karena konsep madrasah diniyah yang teacher centered. kiai merupakan surveyor yang memonitor segala kegiatan guru-guru yang mengajar apabila seorang guru melakukan kesalahan maka guru tersebut akan diberi pengarahan.

Melihat visi madrasah diniyah kebanyakan yang mewujudkan alumninya beraqidah ahlu sunnah wal jamaah maka gurunya juga harus mempunyai aqidah yang kuat. Kiai melakukan penguatan akidah dan perluasan pemahaman lewat rapat internal. Hal ini biasanya kerap dilakukan supaya arah pengajaran tetap pada jalannya. Tidak jarang pula jika seorang guru akan dikeluarkan oleh kiai jika sudah tidak sesuai dengan visi tanpa adanya surat pemecatan.

Falsafah hidup kiai yang khas dengan zuhudnya menjadi potret iklim pembelajaran di madrasah diniyah. Madrasah diniyah seakan berjalan dengan gaya apa adanya yang menekankan pada kualitas santrinya dan menomor duakan kuantitas, walaupaun kuantitas juga menjadi tolak ukur madrasah diniyah tersebut diminati oleh masyarakat sekitar. Harapan dari kiai dengan kualitas santri yang mumpuni maka akan berimplikasi pada kuantitas santrinya. Perihal pendanaan yang menjadi roda penyokong madrasah diniyah ini kebanyakan dari kiai sendiri dan disokong oleh donatur yang peduli terhadap pengembangan madrasah diniyah kedepannya.

Kiai melakukan pengembangan alumni dengan harapan capaian visi mardrsah diniyah akan lebih mudah tercapai. Alumni yang serba bisa akan menjadi alat pasif untuk memperoleh calon calon santri. Adapun metode kiai dalam mengembangkan kemampuan santrinya dilakukan melalui beberapa hal yakni:

1) Metode suri tauladan

Kiai yang nota bene manusia satu satunya dalam madrasah diniyah yang paling dihormati dan disegani. Keluarga kiai juga dikultuskan bahkan santri meyakini bahwa faktor genitas juga mempunyai 
ISTIGHNA, Vol. 2, No 2, Juli 2019 P-ISSN 1979-2824 E-ISSN 2655-8459

Homepage: http://e-journal.stit-islamic-village.ac.id/index.php/istighna

Fatqu Rois dan Himatul Munawaroh Peran Sentralistik Kiai dalam Mengembangkan Pola Manajerial dan Out Put Madrasah Diniyah di Era Milenial

karomah yang luar biasa, apalagi dalam civitas akademik pondok pesantren.

Kiai merupakan suri tauladan bagi santrinya. Kiai adalah aplikator dari sari-sari keislamanan. Singkatnya tidak perlu belajar konsep keislaman secara klasikal namun cukup dengan mengasimilasi semua kegiatan kiai. Kiai selalu melakukan tindakan yang bernafaskan Islam, bukan hanya orang yang bisa berkelakar namun tidak bisa melakukan apa yang dikatakan. Akhirnya santri akan belajar dan berakhlaq dengan sendirinya.

Seoarang kiai biasanya bersifat zuhud, qonaah terhadap riski yang diberikan Allah, melakukan amar ma'ruf nahi munkar. Berlapang dada dan tidak tamak atas apa yang ada padanya dan tidak mendahulukan orang kaya atas orang miskin. Kiai juga bergegas melakukan ibadah, sikapnya tidak kasar dan berbudi luhur. ${ }^{9}$ Sifatisifat ini yang akan diwariskan kepada santri-santri yang belajar di madrasah diniyah sehingga otomatis selain paham dalam hal agama maka santri akan mempunyai sikap berbudi luhur.

Santri diharapkan mampu mempunya bangunan spiritual lewat gaya sang kiai ketika bersikap. Bangunan Spiritual adalah elemen yang sangat penting dan mendasar. Tanpa ada fondasi kehidupan ini maka hidup bagai terpenjara dan menghabiskan waktu sia sia tanpa makna. ${ }^{10}$ Sikap spiritual dapat dimunculkan dalam berserah diri, mengasihi, tak terbatas, pikiran kosong, Murah hati, keterhubungan dan ceria. ${ }^{11}$

Kiai adalah figur yang sangat berpengaruh pada perkembangan kebanyakan madrasah diniyah. Semakin terkenal kiainya maka madrasah diniyah juga akan terkena dampaknya begitupula sebaliknya. Kiai yang terkenal dengan keikhlasan mengajarnya menjadi daya tarik yang luar biasa bagi masyarakat. Kiai tidak digaji untuk memajukan madrasah diniyahnya. Ikhlas menjadi landasan utama kiai dalam menumbuh kembangkan madrasahnya.

2) Ekstra kulikuler

Alumni harus dibekali dengan segudang keterampilan yang bisa langsung dirasakan oleh masyarakat. Alumni madrasah diniyah hendaknya tidak hanya mampu mengaji saja namun juga harus punya kemampuan lain. Madrasah diniyah akan memberikan aktifitas ekstra kulikuler untuk menunjang keterampilan santrinya, adapun ekstra kulikulernya adalah:

a) Hadrah

\footnotetext{
${ }^{9}$ A. Musthofa Bisri, Percik-Percik Keteladanan Kiai Hamid Ahmad Pasuruan (Rembang: Lembaga Informasi dan Studi Islam (L" Islam) Yayasan Ma'had as-Salafiyah, 2003). hlm. xxxvi 25

${ }^{10}$ Priatno H Markoesono, Spiritual Thinking (Bandung: PT Mizan Pustaka, cet I, 2000) hlm.

${ }^{11}$ Wayne W Dyer, Ada Jalan Spiritualitas Bagi Setiap Masalah (Jakarta: PT Gramedia Pustaka Umum, 2005) hlm. 19
} 
ISTIGHNA, Vol. 2, No 2, Juli 2019 P-ISSN 1979-2824 E-ISSN 2655-8459

Homepage: http://e-journal.stit-islamic-village.ac.id/index.php/istighna

Fatqu Rois dan Himatul Munawaroh Peran Sentralistik Kiai dalam Mengembangkan Pola Manajerial dan Out Put Madrasah Diniyah di Era Milenial

Madrasah diniyah memberikan ektra kulikuler ini bertujuan untuk menyalurkan potensi santri yang mempunyai hobi musik. Selain itu manusia tidak lepas dari seni, karena didalamnya termuat keindahan dan naluri manusia. ${ }^{12}$ Efek dari dari hadrah atau bermusik dapat berimplikasi pada kondisi fisik dan psikis seseorang. ${ }^{13}$

Hadrah seni bermusik dalam Islam yang melantunkan nadanada sholawat, dan lagu lagu religi. Seni musik ini mempunyai elemen sentral yakni adanya praktik spiritual didalamnya terdapat ritual yang menggunakan suara manusia yang membacakan syair-syair yang ditujukkan untuk Allah SWT, nabi Muhammad SAW dan para waliyullah. Sehingga hadrah ini digolongkan menjadi music sufi. ${ }^{14}$ Kebanyakan madrasah diniyah memakai seni hadrah al Banjari.

b) Muhafadhah

Muhafadhah adalah kegiatan santri menghafal Al-Quran, Hadist dan Syi'ir. Hafalan adalah metode klasik khas yang menekankan pada daya ingat santri. Santri dibimbing dengan cara drill yaitu pengulangan hafalan secara kontinu. ${ }^{15}$ Tanpa adanya metode drill ini maka hafalan yang diperoleh akan cepat hilang dari ingatan. ${ }^{16}$

c) Muhadharah

Muhadharah diambil dari bahasa Arab yang bermakna ceramah. ${ }^{17}$ Muhadharah adalah kegiatan santri yang berhubungan dengan public speaking Islami. Mereka dijarkan bagaimana menjadi da'i yang berkualitas.

Persiapan, cara penyampaian materi dan penampilan diajarkan dalam kegiatan ini. Bagaimana tidak, santri harus menyampaikan dakwahnya dimimbar dan disaksikan seluruh santri di madrasah diniyah. Inti dari kegiatan ini adalah melatih tingkat kepercayaan diri santri dalam menghadapi masyarakat kelak.

b. Metode pengembangan eksternal

Metode pengembangan eksternal meliputi pengembangan bidang sarana dan prasarana serta koneksi. Madrasah diniyah dibangun atas

\footnotetext{
${ }^{12}$ Darmo budi suseno, Lantunan Shalawat dan Nasyid untuk Melejitkan IQ-EQ-SQ (Yogyakarta: Media Insani, 2005) hlm. 8

${ }^{13}$ Mustamir, 5 Metode Penyembuhan dari Langit (Yogyakarta: Lingkungan, 2008) hlm. 1-2

${ }^{14}$ Carl W Ernest, Ajaran dan Amaliah Tasawuf, terj. Arif Anwar (Yogyakarta: Pustaka Sufi, 2003) hlm. 254

${ }^{15}$ Yahya Abdul Fatttah Az Zamawi Al Hafidz, Revolusi Menghafal Al-Quran: Cara Menghafal, Kuat Hafalan dan Terjaga Seumur Hidup (Surakarta: Insan Kamil, 2010) hlm. 86

${ }^{16}$ Muhammad Habillah Muhammad Asy-Syinqithi, Kiat Mudah Menghafal Qur'an (Solo: Gazzamedia, 2011) hlm. 87

${ }^{17}$ Ahmad Warson Munawir, Kamus Arab - Indonesia Al-Munawir (Surabaya: Pustaka Progresif, 1997) hlm. 274
} 
ISTIGHNA, Vol. 2, No 2, Juli 2019 P-ISSN 1979-2824 E-ISSN 2655-8459

Homepage: http://e-journal.stit-islamic-village.ac.id/index.php/istighna

Fatqu Rois dan Himatul Munawaroh

Peran Sentralistik Kiai dalam Mengembangkan Pola Manajerial dan Out Put

Madrasah Diniyah di Era Milenial

dasar dakwah Islamiyah tanpa ada embel-embel lainnya. Efeknya segala aktifitas administrasi dicukupi langsung oleh madrasah diniyah.

Santri hendaknya ditempatkan pada ruang kelas yang representatif supaya bisa mendapatkan kenyamanan dalam belajar. Ruang madrasah diniyah kebanyakan hanya berwujud kelas tanpa ada taman atau sarana penunjang lain. Isi dari kelas tersebut adalah meja guru, papan tulis dan meja santri.

Kiai dan pengurus madrasah diniyah kiranya "puas" dengan pembuatan kelas yang klasikal. Mereka berfikir bahwa ruang kelas adalah wadah penunjang kegiatan pembelajaran saja. Urgensi dari pembelajaran Islam adalah kegiatan transfer pengetahuan dan nilai nilai keislaman, jadi kelas bukanlah hal utama yang harus diperhatikan selama tidak mengganggu kegiatan belajar santri.

Madrasah diniyah dibangun dengan desain minimalis yang mengesampingkan aspek keindahan menjadi ciri khas institusi ini. Desain kelas dan pembangunannya diprakarsai oleh kiai, bisa dikatakan kiai adalah orang yang serba bisa. Penataan ruang kelas dengan model klasikal yakni dengan model bangku guru berhadapan dengan bangku santrinya sangat jarang ditemukan ruang kelas dengan model u (meja guru ditengah dan meja santri mengitarinya membentuk huruf $\mathrm{u}$ ). Fungsi Ruang kelas memang difungsikan untuk media mencari ilmu, namun bukan hal yang salah jika ruang kelas ditata menjadi tempat yang nyaman dengan menambahkan aksen aksen baru yang menunjang pembelajaran sehingga mereka betah diajar gurunya dan prosentase keberhasilan memahamai materi akan meningkat.

Kiai dalam mengembangkan madrasah diniyah juga banyak melakukan kerjasama dengan pihak pihak yang kiranya mau dan mampu memajukan madrasah diniyah. Bantuan dari pihak pihak lain inilah yang lebih bisa menyokong arah madrasah diniyah. Bantuan tersebut berupa dukungan moral/motivasi dan material. Ketika antara kiai dan pihak pihak ini saling terhubung maka apabila madrasah diniyah mengalami masalah maka akan segera teratasi secara efektif dan efisien.

Kiai diharapkan bukan hanya menjadi insan yang hanya menguasai satu bidang ilmu saja namun juga harus berwawasan luas bagaimana caranya agar institusinya tidak mati. Kiaipun ada yang bertransformasi menjadi wakil rakyat dalam usahanya memperluas koneksi untuk mengembangkan kondisi madrasah diniyahnya. Tak pelak jika pamor kiai dalam masyarakat turun karena beberapa masalah misalnya adanya tindakan kiai yang melanggar aturan maka masa depan madrasah diniyahpun juga akan menjadi taruhannya. Jadi kiai bagaikan mata pisau bagi madrasah diniyah satu sisi dapat meningkatkan pamor dan sisi yang lain akan bermasalah jika kiainya sudah tidak mempunyai 
ISTIGHNA, Vol. 2, No 2, Juli 2019 P-ISSN 1979-2824 E-ISSN 2655-8459

Homepage: http://e-journal.stit-islamic-village.ac.id/index.php/istighna

Fatqu Rois dan Himatul Munawaroh Peran Sentralistik Kiai dalam Mengembangkan Pola Manajerial dan Out Put Madrasah Diniyah di Era Milenial

karisma lagi apa lagi jika kiainya sudah meninggal dunia apabila pengganti kiai tidak mempunyai kharisma yang sama. ${ }^{18}$

\section{Kritik terhadap Madrasah Diniyah dan Gaya Sentral Kiai}

Kiai adalah pucuk pimpinan dalam madrasah diniyah. Otoritarian kiai sangat terasa dalam manajerial madrasah diniyah. Kebanyakan kiai juga tetap mengajar di madrasah diniyah bukan seperti kepala sekolah yang sibuk mengurusi manajerial institusinya. Hal ini yang membedakan antara pemimpin sekolah yang menunaikan tugas cukup dengan mengurus manajerial yang ditugaskan kepadanya dari pusat tanpa perlu mengajar. Sementara kiai mempunyai peran ganda satu sisi harus mengurusi manajerial madrasah dan satu sisi yang lain masih harus mengajar santrinya karena kiai mempunyai tanggung jawab untuk memelihara kualitas lulusan bahkan rela sampai mendidik secara langsung dengan demikian kiai mempunyai ikatan bathin yang kuat dengan santrinya. Pada tataran inilah daya kharismatik dan segan antara kiai-santri sangat berbeda dengan kepala sekolah-muridnya.

Kelebihan dari manajerial dengan keterpemimpinan terpusat adalah semua bisa dikendalikan dari atas dan semua bentuk kegiatan dapat dipantau dengan baik. Kiai tidak mungkin bekerja sendirian dalam mengembangkan madrasah diniyahnya. Tim yang dibentuk oleh kiai biasanya lebih bersifat homogen terlebih dalam hal ideologi keislaman. Sangat jarang ditemui seorang kiai berbeda paham dengan anggota timnya. Hal ini kiranya akan menghambat kemajuan dari madrasah diniyah.

Masalah madrasah diniyah lumayan kompleks dari ijazah yang yang tidak mempunyai kekuatan legal, kurangnya perhatian dari pemerintah, belum lagi tersandung masalah internal misalnya gagalnya perkaderan santri baru. Perkaderan santri yang ada didalam madarasah diniyah bersifat menunggu calon santri datang, hal ini bertolak belakang dengan sekolah umum yang menjemput calon peserta didiknya bahkan dengan berbagai fasilitas yang diberikan secara cuma-cuma. Mungkin hal-hal diatas menjadikan madrasah diniyah tidak begitu diminati masyarakat sekitar.

Kiai lebih mengutamakan keistiqomahan dalam mencetak output lulusan madrasah diniyahnya. Menjaga tradisi keilmuan bukan hal yang mudah. Lulusan dari awal sampai saat ini kadang tidak bisa berfikir modern padahal masalah dalam masyarakat semakin kompleks. Pelajaran dalam madrasah diniyah yang nota bene berkutat pada ajang Kawasan syariat saja dan terkadang bersifat statis-tradisionalis. Hendaknya lulusan tetap menjaga wawasan keislaman disisi lain harus bisa menjadi pemecah masalah diera yang serba teknologi seperti saat ini. Disinilah peran penting kiai dalam memecah kebuntuan yang dihadapi madarasah diniyah apakah harus tetap bertahan atau harus bertransformasi menjadi format madrasah diniyah baru.

Kiai harus memperluas wawasan bagimana membuat formula baru untuk tetap menjaga eksistensi instansinya bahkan bisa menjadikan

${ }^{18}$ Saiful Akhyar Lubis, Konseling Islami Kiai dan Pesantren (Yogyakarta:eLSAQ Press, 2007) hlm, 169 
ISTIGHNA, Vol. 2, No 2, Juli 2019 P-ISSN 1979-2824 E-ISSN 2655-8459

Homepage: http://e-journal.stit-islamic-village.ac.id/index.php/istighna

Fatqu Rois dan Himatul Munawaroh

Peran Sentralistik Kiai dalam Mengembangkan Pola Manajerial dan Out Put

Madrasah Diniyah di Era Milenial

madrasah diniyah sebagai poros pertumbuhan pesatnya pemikiran keislaman. Kiai harus memperluas koneksi dengan berbagai pihak supaya madrasah diniyah bisa bermanuver lebih leluasa terutama dalam penguatan softskill dan hardskill lulusan.

Kiai dan guru di madrasah diniyah biasanya menggunakan cara klasikal dalam mengajar yakni sorogan, bandongan dan wetonan.19 Guru hendaknya menggunakan media pemberlajaran modern seperti LCD Proyektor untuk memudahkan dan memberi kesan menarik dalam pembelajarannya. Sangat jarang ditemui pula dalam madrasah diniyah adanya rekreasi, hal ini ditujukan untuk menyemangati santri untuk selalu istiqomah dalam belajar. Rekreasi ditujuakan pada tempat tempat yang masih ada hubungannya dengan budaya keislaman contoh zaiarah ke makam makam wali songo.

Madrasah diniyah hendaknya juga memberikan fasilatas berupa ekstrakulikuler yang dapat menunjang kreatifitas santri. Ekstrakulikuler ini bertujuan sebagai wadah bakat dan minat santri yang sudah barang tentu disesuaikan dengan kemampuan baik dari segi finansial ataupun SDM yang dimiliki madrasah diniyah. Madrasah diniyah juga dapat menguatkan kompetensi guru berupa pelatihan dan studi banding ke madrasah dinyah yang dinilai reperenstatif dengan visi dan misi.

Kiai harus secepatnya memilih model madrasah diniyahnya apakah memakai sistem madrasah diniyah independen dengan pengajaran pelajaran Islam murni atau madrasah diniyah hybrid yang memadukan antara madrasah diniyah dengan sekolah formal. Kiai dan semua yang terlibat dalam madrasah harus merespon keinginan masyarakat saat ini. Jika kiai tetap bersih kukuh dengan model independent maka pekerjaan kiai adalah bagaimana membuat madrasah tersebut punya daya tarik luar biasa sehingga instansi pembelajaran Islam ini tetap eksis.

\section{KESIMPULAN}

Kiai sebutan bagi seseorang yang mengajarkan tentang ilmu agama Islam di Indonesia yang mempunyai peranan penting bagi masyarakat. Seorang kiai mempunyai berbagai metode dalam mensyiarkan agama islam di masyarakat salah satunya adalah berbasis Madrasah diniyah. Kiai sebagai penentu arah madrasah diniyah tentu mempunyai pengaruh yang sangat kuat, sehingga maju mundurnya suatu madrasah diniyah tergantung dari pola pikir dan tindak tanduk dari kiainya. Kiai harus mengetahui problematika yang ada dalam madrasah diniyah serta harus mampu membuat metode-metode praktis guna memperkuat lulusannnya. Kiai juga hendaknya memperluas wawasan dan koneksi supaya madrasah diniyah tetap eksis dan bisa memberikan lulusan yang bisa mandiri di masyarakat.

${ }^{19}$ Hasbullah, Sejarah Pendidikan Islam di Indonesia (Jakarta: Raja Grafindo Persada, 2001) hlm. 145 
ISTIGHNA, Vol. 2, No 2, Juli 2019 P-ISSN 1979-2824 E-ISSN 2655-8459

Homepage: http://e-journal.stit-islamic-village.ac.id/index.php/istighna

Fatqu Rois dan Himatul Munawaroh Peran Sentralistik Kiai dalam Mengembangkan Pola Manajerial dan Out Put Madrasah Diniyah di Era Milenial

\section{REFERENSI}

Amin, Haedar dan Elsaha Isham, Peningkatan Mutu Terpadu Pesantren dan Madrasah Diniyah (Jakarta: Diva Pustaka, 2004)

Al Hafidz, Yahya Abdul Fatttah Az Zamawi, Revolusi Menghafal Al-Quran: Cara Menghafal, Kuat Hafalan dan Terjaga Seumur Hidup (Surakarta: Insan Kamil, 2010)

Asy-Syinqithi, Muhammad Habillah Muhammad, Kiat Mudah Menghafal Qur'an (Solo: Gazzamedia, 2011)

Bisri, A. Musthofa, Percik-Percik Keteladanan Kiai Hamid Ahmad Pasuruan (Rembang: Lembaga Informasi dan Studi Islam (L" Islam) Yayasan Ma'had as-Salafiyah, 2003).

Direktorat Pendidikan Keagamaan \& Pondok Pesantren Dirjen Kelembagaan Agama Islam, Pedoman Penyelenggaraan dan Pembinaan Madrasah Diniyah, (Jakarta: Departemen Agama RI, 2003)

Dhofier, Zamakhsyari, Tradisi Pesantren: Study tentang Pandangan Hidup Kiai (Jakarta: LP3S, 1982)

Dyer, Wayne W, Ada Jalan Spiritualitas Bagi Setiap Masalah (Jakarta: PT Gramedia Pustaka Umum, 2005)

Ernest, Carl W, Ajaran dan Amaliah Tasawuf, terj. Arif Anwar (Yogyakarta: Pustaka Sufi, 2003)

Hasbullah, Sejarah Pendidikan Islam di Indonesia (Jakarta: Raja Grafindo Persada, 2001)

Lubis, Saiful Akhyar, Konseling Islami Kiai dan Pesantren (Yogyakarta:eLSAQ Press, 2007)

Rasyid, Hamdan, Bimbingan Ulama; Kepada Umara dan Umat (Jakarta: Pustaka Beta, 2017)

Markoesono, Priatno H, Spiritual Thinking (Bandung: PT Mizan Pustaka, cet I, 2000)

Muhaimin, Paradigma Pendidikan Islam, (Bandung: PT. Remaja Rosdakarya, 2004)

Munawir, Ahmad Warson, Kamus Arab - Indonesia Al-Munawir (Surabaya: Pustaka Progresif, 1997)

Mustamir, 5 Metode Penyembuhan dari Langit (Yogyakarta: Lingkungan, 2008)

Rasyid, Hamdan, Bimbingan Ulama: kepada Umara' dan Ummat (Jakarta: Pustaka Beta, 2007).

Saha, M. Ishom, Dinamika Madrasah Diniyah di Indonesia :Menelusuri Akar Sejarah Pendidikan Nonformal (Jakarta: Pustaka Mutiara, 2005)

Suseno, Darmo Budi, Lantunan Shalawat dan Nasyid untuk Melejitkan IQ-EQ-SQ (Yogyakarta: Media Insani, 2005) 